\title{
SÍTIO ARQUEOLÓGICO TRÊS FRONTEIRAS № 7 Um Abrigo do Holoceno Médio no Alto Araçuaí, Minas Gerais
}

\section{TRÊS FRONTEIRAS ARCHAEOLOGICAL SITE № 7 \\ A Shelter of The Mid-Holocene in the Araçuaí River Basin, Minas Gerais}

\author{
Alessandra Mendes Carvalho Vasconcelos ${ }^{1}$ \\ alessandra.carvalho@ict.ufvjm.edu.br \\ Alexandre Christófaro Silva ${ }^{2}$ \\ alexandre.christo@ufvjm.edu.br
}

\author{
Marcelo Fagundes ${ }^{3}$ \\ marcelofagundes.arqueologia@gmail.com \\ Matheus Kuchenbecker ${ }^{1}$ \\ matheusk@ict.ufvjm.edu.br \\ Valdinêy Amaral Leite ${ }^{4}$ \\ valdineyal@msn.com
}

\section{RESUMO}

Este artigo tem como objetivo apresentar uma síntese das intervenções realizadas no Complexo Arqueológico Três Fronteiras, uma área que até o momento apresentou um total de 16 abrigos sob rocha quartzítica, todos com marcas evidentes de ocupação humana. A área está localizada na Serra do Espinhaço Meridional, mais precisamente em sua face leste (Serra Negra), nordeste de Minas Gerais, na bacia do Araçuaí, municípios de Felício dos Santos e de Senador Modestino Gonçalves. O abrigo n⿳ 7 foi escavado por uma equipe multidisciplinar com a intenção de obter datas e repertório cultural para posteriores análises e discussões com os resultados de outros sítios regionais escavados. Logo, o sítio Três Fronteiras $\mathrm{n}^{\mathrm{o}} 7$ obteve data de $4100 \pm 30$ anos AP. situando sua ocupação durante o Holoceno Médio, resultado comum para outros abrigos locais.

PALAVRAS-CHAVE: Serra do Espinhaço Meridional, Holoceno Médio, Três Fronteiras, Paleoambiente.

\footnotetext{
${ }^{1}$ Instituto de Ciências e Tecnologia, UFVJM.

${ }^{2}$ Faculdade de Ciências Agrárias, UFVJM.

${ }^{3}$ Faculdade Interdisciplinar em Humanidades, UFVJM.

${ }^{4}$ Pesquisador, Laboratório de Arqueologia e Estudo da Paisagem, LAEP/UFVJM.
} 


\begin{abstract}
The objective of this article is to summarize the interventions so far carried out within the Três Fronteiras Archaeological Complex, composed by 16 quartzite rock shelters with outstanding evidences of human occupation. The area is located in the eastern border of the southern Espinhaço range (Serra Negra), in which is drained by the Araçuaí river basin, in the municipalities of Felício dos Santos and Senador Modestino Gonçalves, Minas Gerais. The shelter $\mathrm{n}^{\mathrm{o}} 7$ was excavated by a multidisciplinary team with the intention of obtaining ages and material culture for further analysis and comparison with other archaeological sites. The oldest evidence of occupation within the site was dated in $4100 \pm 30 \mathrm{yr}$ BP. (Mid Holocene), which is coherent with the chronologies found in other sites.
\end{abstract}

KEY WORDS: Espinhaço Meridional Range, Mid-Holocene, Três Fronteiras, Landscapes, Paleoenvironment.

\title{
CONTEXTO DA PESQUISA
}

O Complexo Arqueológico de Três Fronteiras está localizado na face leste da Serra do Espinhaço Meridional (SdEM), municípios mineiros de Felício dos Santos e Senador Modestino Gonçalves. Até o momento o Complexo está constituído por 16 sítios arqueológicos em abrigos sob rocha, com presença marcante de grafismos. Trata-se de uma área de afloramentos quartzíticos em meio ao cerrado stricto sensu que, dadas às especificidades geoambientais locais, surge como uma ilha constituída por campos rupestres e campos ralos, entre dois vales estabelecidos pelas micro-bacias dos córregos Lambari Dourado ao norte (município de Senador Modestino Gonçalves), e do Água Quente ao sul (município de Felício dos Santos), (Figura 01). 
Ao leste/ sudeste um marco geográfico local está representado pela imponência da Serra do Bocaina (ou Miranda), composta por camadas de quartzito que mergulham para leste, cortadas por planos de fratura verticais onde, mesmo com vários pequenos abrigos, não há vestígios aparentes de ocupações (Figura 2). Ainda a leste, a Pedra Menina é outro marco geográfico de suma importância regionalmente e a nordeste se faz presente a Serra Dois Irmãos e a Serra do Ambrósio, esta última importante área geográfica do SdEM, berço de várias espécies endêmicas. Ao sul a Chapada do Couto (Serra do Gavião) é outro marco geográfico que abriga sítios arqueológicos importantes de Felício dos Santos, sobretudo os implantados em Floresta Estacional Semidecidual, a exemplo dos sítios Cabeças, Sampaio e Jambreiro, ambos com cronologias de ocupações relacionadas ao Holoceno Médio, (Figura 1).

De certo modo, o Complexo Três Fronteiras, juntamente com Campo das Flores (mais ao nordeste, no sopé da Serra dos Irmãos - Figura 01), trazem consigo as especificidades de estarem implantados em campos rupestres, com grandes afloramentos quartzíticos que formam abrigos favoráveis ao estabelecimento humano, em áreas cercadas pelo domínio fitoecológico do cerrado, mas também não tão distantes de manchas de Floresta Estacional Semidecidual e, desta forma, com diferentes recursos naturais disponíveis e em abundância. 


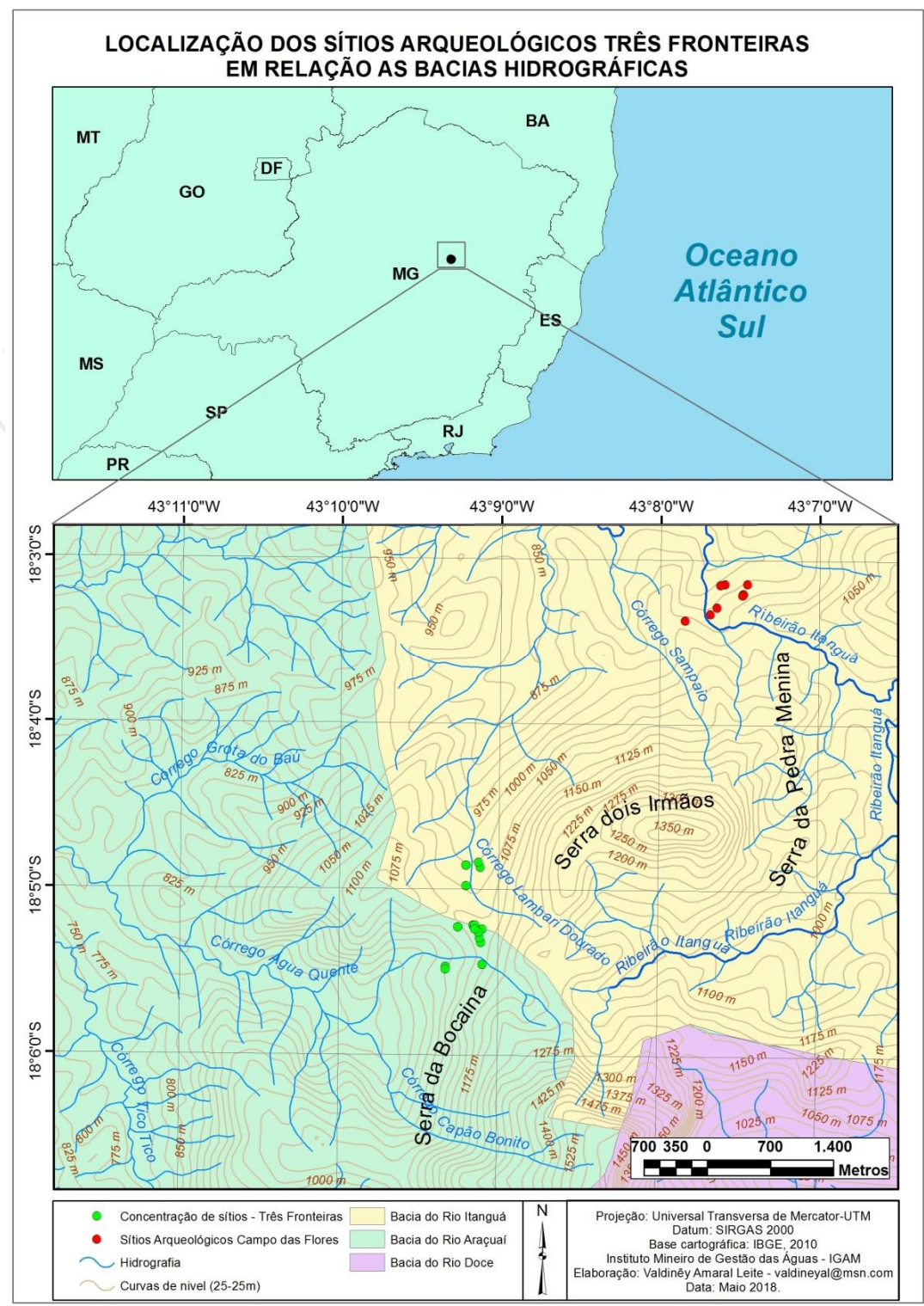

Figura 1. Mapa de localização do Complexo Três Fronteiras. Fonte: IGAM. 
Mais recentemente, a expansão das atividades de mineração tem ameaçado estes locais, para além da preservação do abrigo em si, mas, sobretudo da paisagem que abarca os sítios e lugares. Temos partido do princípio que, apesar da nomeação arbitrária dos abrigos (considerados entidades únicas exclusivamente para nossas análises), Três Fronteiras como um todo é um grande sítio arqueológico. Seus abrigos são células de uma paisagem complexa, organizada e dinâmica, que foram ocupados e significados em longa duração e que, somadas suas características topogeoambientais, estabeleceram um núcleo ocupacional para além da noção de sítio arqueológico, isto é, trata-se de um lugar (Binford, 1982).

Logo, pode-se caracterizar o Complexo Arqueológico Três Fronteiras como um enclave ambiental-arqueológico em que Humanos puderam desenvolver suas atividades (de várias ordens).

Como discutiremos a seguir, como norte teórico-metodológico, temos utilizado o conceito de paisagem, aqui compreendida como uma entidade para além de suas características físicas (geoambientais), uma vez que, apesar da grande relevância, outras categorias se somam. Sua constituição se dá a partir das interações entre Humanos e seus ambientes, bem como da própria dinâmica social, envolvendo questões de várias ordens (econômica, simbólica, cosmológica, política, moralideológica, religiosa, etc.). Nesta perspectiva, seus portadores a interpretam, dão sentido e sentimentos ao lugar em que habitam. Depende de percepção, de visão de mundo (e da vida) e não necessariamente da modificação/ transformação, 
apesar de que estas ações também estejam intimamente atreladas ao modo que as pessoas vêem, classificam e percebem o mundo à sua volta (Zvelebil, 1997). A paisagem se estabelece por meio das inter-relações entre pessoas, objetos, formas e percepções que se dão a partir de processos históricos, ambientais e contextuais.

De certo modo, o Complexo Três Fronteiras, juntamente com Campo das Flores (mais ao nordeste, no sopé da Serra dos Irmãos - Figura 1), trazem consigo as especificidades de estarem implantados em campos rupestres, com grandes afloramentos quartzíticos que formam abrigos favoráveis ao estabelecimento humano, em áreas cercadas pelo domínio fitoecológico do cerrado, mas também não tão distantes de manchas de Floresta Estacional Semidecidual e, desta forma, com diferentes recursos naturais disponíveis e em abundância.

Mais recentemente, a expansão das atividades de mineração tem ameaçado estes locais, para além da preservação do abrigo em si, mas, sobretudo da paisagem que abarca os sítios e lugares. Temos partido do princípio que, apesar da nomeação arbitrária dos abrigos (considerados entidades únicas exclusivamente para nossas análises), Três Fronteiras como um todo é um grande sítio arqueológico. Seus abrigos são células de uma paisagem complexa, organizada e dinâmica, que foram ocupados e significados em longa duração e que, somadas suas características topogeoambientais, estabeleceram um núcleo ocupacional para além da noção de sítio arqueológico, isto é, trata-se de um lugar (Binford, 1982). 
Logo, pode-se caracterizar o Complexo Arqueológico Três Fronteiras como um enclave ambiental-arqueológico em que Humanos puderam desenvolver suas atividades (de várias ordens).

Como discutiremos a seguir, como norte teórico-metodológico, temos utilizado o conceito de paisagem, aqui compreendida como uma entidade para além de suas características físicas (geoambientais), uma vez que, apesar da grande relevância, outras categorias se somam. Sua constituição se dá a partir das interações entre Humanos e seus ambientes, bem como da própria dinâmica social, envolvendo questões de várias ordens (econômica, simbólica, cosmológica, política, moralideológica, religiosa, etc.). Nesta perspectiva, seus portadores a interpretam, dão sentido e sentimentos ao lugar em que habitam. Depende de percepção, de visão de mundo (e da vida) e não necessariamente da modificação/ transformação, apesar de que estas ações também estejam intimamente atreladas ao modo que as pessoas vêem, classificam e percebem o mundo à sua volta (Zvelebil, 1997). A paisagem se estabelece por meio das inter-relações entre pessoas, objetos, formas e percepções que se dão a partir de processos históricos, ambientais e contextuais. 


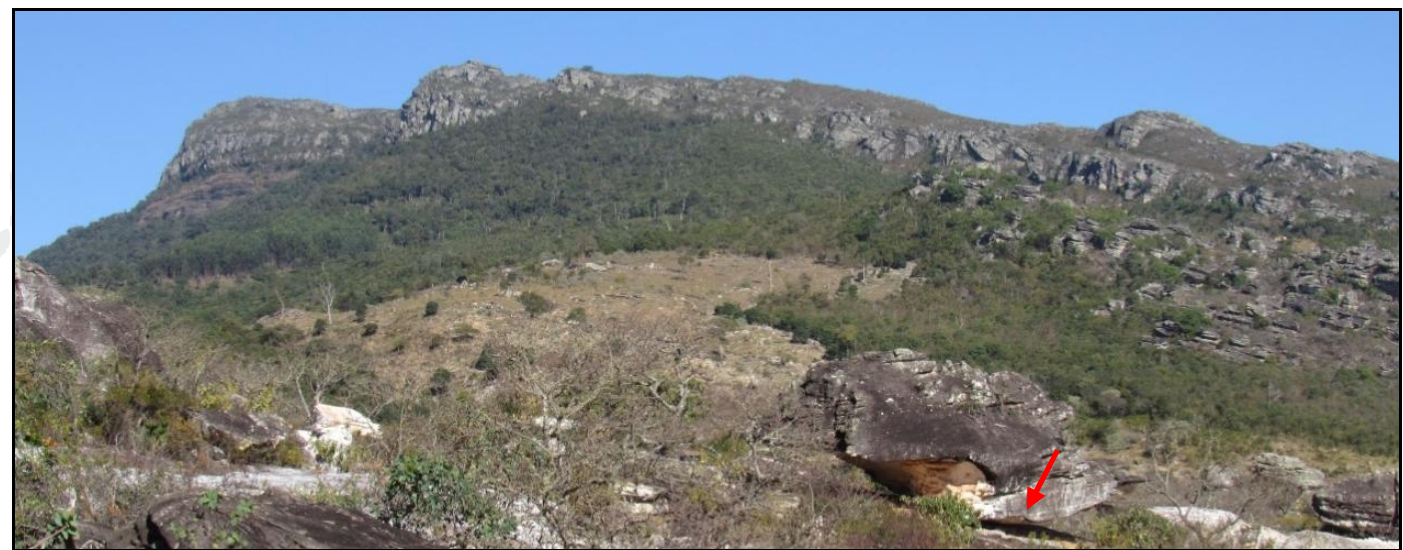

Figura 2. Marco geográfico a leste/sudeste de Três Fronteiras: Serra da Bocaina (ou Miranda). Destaque para o sítio Três Fronteiras 1.

Tendo em mente estes pressupostos, sintetizamos da seguinte forma as principais características da área de estudo aqui apresentada:

- O Complexo Três Fronteiras está implantado entre dois vales que cortam a área de norte a sul, rodeados de serras, algumas delas marcos geográficos que, atualmente, guiam e dão dinamismo a paisagem. Através destes marcos as pessoas hoje se localizam e estabelecem caminhos, se identificam e situam-se enquanto agentes sociais dão referência às suas histórias e ancestralidade para constituírem suas identidades e se distinguirem dos outros (Macedo, 2017);

- Trata-se de um lugar onde os afloramentos de quartzito ganham destaque em meio ao campo rupestre. $\mathrm{O}$ solo arenoso, de tonalidade clara, entre rochas e a vegetação rala permitem a visualização em destaque de todo o entorno; 
- Ao mesmo tempo em que se destaca no entorno, Três Fronteiras permite uma excelente visibilidade do que está em sua volta: para o sul um amplo espaço em direção a Chapada do Couto (um importante marco geográfico durante a exploração do diamante entre os séculos XVIII e XIX), para o norte, todo o vale do rio Araçuaí, um dos caminhos naturais para o nordeste de Minas Gerais e do país. Permite, assim, proteção/ segurança para seus ocupantes, ao mesmo tempo em que é um ponto de fixação (e apoio) central para exploração do entorno (e suas possibilidades de ecótono);

- Em meio aos quartzitos, veios de quartzo ganham destaque na paisagem regional, fornecendo ampla disponibilidade de matéria-prima para indústria lítica. Disponibilidade, portabilidade e flexibilidade são conceitos marcantes para quem estuda conjuntos líticos desta região. O dióxido de ferro é outro mineral abundante que aflora na face nordeste do sítio 06 ;

- Os recursos hídricos são permanentes, como dito, sendo cortado por duas bacias diferentes, garantindo o fornecimento de água, além de outros recursos associados: pesca, por exemplo.

Estas condições geoambientais disponibilizaram uma diversidade de recursos para ocupação do lugar, sobretudo partindo do pressuposto que, no que tange às características fitoecológicas regionais, ocorreram poucas mudanças ao longo do período que a região apresentou cronologias de ocupação. Como discutiremos a seguir, para área obtiveram-se datas a partir do Holoceno Médio até muito próximo ao contato que, a priori, nos permite inferir que se trata de lugares com ocupações contínuas, característica que corrobora para nossa hipótese que o Complexo Três Fronteiras abriga qualidades próprias, em muitos modos, à manutenção da vida Humana. 
Frente a este universo de possibilidades, em julho de 2017 o abrigo Três Fronteiras $\mathrm{n}^{\mathrm{0}} 7$ foi eleito para escavação. O objetivo principal da intervenção era obter datas e repertório cultural para posteriores análises e discussões com os resultados de Campo das Flores, uma área com característica topogeoambientais similares e que teve o sítio Itanguá $\mathrm{n}^{\mathrm{o}} 2$ escavado, com cronologias próximas ao século XIV de nossa Era para o primeiro pacote de ocupação (no pacote mais profundo não foi obtido material para datação), bem como com os resultados do sítio Sampaio datado em $4280 \pm 30$ anos AP (BETA 471280) e dos sítios Cabeças, em especial o Cabeças 04, com sequência de ocupação entre 7225 e 4420 anos AP, estes dois últimos sítios, também abrigos quartzíticos, com datações relacionadas ao Holoceno Médio, tendo como principal característica cultural a presença marcante de grafismos com temáticas associadas à tradição Planalto e indústrias líticas em quartzo, tendo o lascamento unipolar como a principal técnica utilizada.

Logo, as ações em Três Fronteiras foram associadas ao projeto guarda-chuva ${ }^{5}$, que tem como pergunta-chave: Como se deu as relações entre humanos em seus ambientes em termos holísticos e diacrônicos no Alto Vale do Jequitinhonha, e quais e como os vestígios arqueológicos/ culturais podem cooperar para compreensão da ocupação e uso dos lugares durante o Holoceno?

\footnotetext{
${ }^{5}$ Financiado pelo CNPq.
}

Indexadores: Latindex, ISIS, Google Academic 
Este artigo, em especial, tem como objetivo trazer uma síntese das características geoambientais (e paleoambientais) e de implantação do Complexo Arqueológico Três Fronteiras, bem como descrevendo os processos interventivos e seus resultados no que tange à cronologia e repertório cultural obtidos. Por fim, com base nestes dados, apresentaremos uma discussão sobre as ocupações em abrigo durante o Holoceno Médio em Serra Negra, indicando os avanços obtidos até então e os procedimentos teórico-analíticos que têm cooperado para a compreensão deste continuum ocupacional durante o Holoceno para o Planalto Diamantinense e Serra Negra, áreas componentes da Serra do Espinhaço Meridional, (Isnardis, 2009, 2013; Fagundes, 2016).

\section{SÍNTESE DAS ABORDAGENS TEÓRICAS: PAISAGEM COMO ESCOPO}

Faz algum tempo que a pesquisa aqui apresentada tem se guiado teórica, e metodologicamente, pelo conceito de paisagem, entendida por meio das interações e da dinâmica sócio-ocupacional, que envolvem questões de ordem cosmológica, simbólica, política, ideológica, por exemplo, e, portanto, seus portadores a interpretam, dão sentido e sentimentos aos lugares em que habitam. Estabelecerse, criar e modificar, bem como ocupar ou abandonar uma área, nesta prerrogativa, diz respeito às escolhas efetuadas pelo grupo que estão além de possibilidades ecológico-adaptativas, mas que dizem respeito à vida como um todo (Zvelebil, 1997), ao processo de significação e ordenamento na natureza indicado pelo geógrafo Denis Cosgrove (1984). 
As paisagens estão constituídas por lugares, estabelecidos e experimentados pelo sujeito (s) de acordo com suas ontologias (Zvelebil, 1997). Trata-se de um produto humano, de uma construção, podendo ser definida como um espaço social humanizado: no tempo, no espaço e na cultura. No caso apresentado, os diferentes abrigos - aqui entendidos como um todo, um único lugar ou sítio por assim dizer, compondo estratégias de usos e desempenhos diferenciados ao longo do tempo -, apresentam características que ultrapassam suas possibilidades geoambientais e, portanto, a ocupação da área resultou de um modo eficaz de regulação entre diferentes fatores em suas estruturas sócio-culturais (ambiental-adapativos, moralreligioso, político, etc).

As paisagens são ações e ideias que permitem a vida, para além de uma somatória de ambientes construídos, uma vez que são dinâmicas, vistas como um texto histórico e que funcionam como um sistema de manipulação simbólica (Cosgrove, 1984), características que permitem que sejam experimentadas, percebidas e contextualizadas (Knapp; Ashmore, 1999; Zvelebil, 1997).

Constituídas por Humanos, são moldadas por meio de suas experiências ao longo do tempo. Se o mundo sempre é resultado da práxis humana, as paisagens também são. São as pessoas que criam/ estabelecem paisagens, projetando ideias/ sentimentos para o mundo a partir deste mundo e, portanto, fazem parte da vida, da construção social do espaço em si (Troncoso, 2001): 
Podemos concebir el paisaje entonces como un elemento más dentro de la materialidad del mundo construido por el ser humano, donde su materialidad reside en su configuración natural que es disgregada y filtrada por el caleidoscopio cultural humano. El espacio físico natural es materia prima apropiada y modelada en la producción social del paisaje, es transformado en social, cultural e histórico (...) A partir de su conjugación, relaciones de poder, prácticas de dominación y subversión son posibles de realizar; el paisaje es entonces campo de lucha, lugar para la praxis y la reproducción-subversión de relaciones sociales (Troncoso, 2001, p. 05).

$\mathrm{Na}$ perspectiva aqui adotada, transformar o lugar (reconstruí-lo, permanecer ou abandonar, ressignificá-lo) é um processo de escolhas que envolvem negociações, contratos, trocas e concessões, uma vez que, como discutido por Troncoso (2001), a paisagem é um campo de discurso, sendo que, além disso, as "potencialidades da paisagem" podem ser utilizadas como ferramenta política. Logo, ela reflete o uso social da terra, por indivíduos e comunidades, ao longo do processo histórico (complexo por si), onde as diferentes atividades da vida humana modificam e culturalizam sua constituição, visto que são criadas e modificadas pela história. Se a escolha-primeira pela ocupação é ambiental (possibilidades em si), o conhecimento e consequente "culturalização" estabelecem apegos sobre onde, porque e como se estabelecer.

Justamente por isso, os lugares constitutivos da paisagem se estruturam por meio de elementos dinâmicos e interativos, sempre entendidos, significados/ ressignificados por seus ocupantes. Estão além de representações (ao modelo 
ocidental), uma vez que são concretos (tanto os lugares físicos, quanto os mágicoimaginários), sendo palcos das estruturas que compõem a vida em sociedade.

Nesta perspectiva, a paisagem sempre está in motion, sendo modelada pelas experiências e reativada pelas interrelações entre o mundo e humanos, em que os aspectos cognitivos permitem que esta paisagem seja experimentada, percebida, classificada e contextualizada, onde o indivíduo (ou grupo de) pode dar sentidos inerentes ao contexto histórico de que faz parte, por isso acreditamos que continuidade e/ou mudanças são escolhas. Paisagens são histórias de vida (Zvelebil, 1997). Neste sentido, mantém-se dinâmica (construção - reconstrução, modelagem - remodelagem, estrutura - desestrutura), onde os Humanos se encontram intimamente relacionados. Paisagem e pessoas se conectam em um movimento contínuo, se limitam e se modificam ao longo da história.

O complexo de Três Fronteiras está sendo entendido a partir desta conjetura. Para além de pressupostos teóricos e futuras interpretações e análises, foi fundamental o estabelecimento de uma série de dados (arqueológicos e ambientais), obtidos de modo interdisciplinar, permitindo o a organização de categorias e modelos para compreensão mais assertiva acerca da dinâmica ocupacional da área, visto que, conforme Cosgrove (1998), a natureza só obtém forma e coerência por meio das atividades humanas, estas relacionadas diretamente à significação, ou seja, os modos particulares de conceber e creditar o mundo. Neste sentido, também compartilhamos das ideias de Andrés Troncoso (2001), uma vez que entendemos 
a paisagem como espaço de negociação e discurso histórico. De qualquer forma, não se trata de algo novo, muito menos de algo fácil, sobretudo porque se trata de um olhar para o passado a partir de conceitos atuais.

\section{CARACTERÍSTICAS GEOAMBIENTAIS DO COMPLEXO TRÊS FRONTEIRAS}

A Serra do Espinhaço Meridional (SdEM) atravessa, em direção aproximadamente norte-sul,o estados de Minas Gerais e Bahia, materializando o divisor de águas entre três importantes bacias hidrográficas brasileiras (dos rios São Francisco, Jequitinhonha e Doce).

Devido à sua disposição geomorfológica, diferentes biomas se formaram em suas vertentes, com maior predomínio do cerrado, também em suas variações fitoecológicas. Na borda leste, onde a pesquisa tem sido desenvolvida, há grandes áreas de Mata Atlântica (Floresta Estacional Semidecidual), sobretudo junto às serras limítrofes com a bacia do rio Doce.

Geologicamente, a área do Complexo Arqueológico Três Fronteiras encontra-se inserida no Orógeno Araçuaí, um dos mais importantes componentes geotectônicos da América do Sul. Este orógeno registra uma das várias cadeias de montanhas formadas nesta região do globo no fim do Neoproterozoico (c. 550 Ma), em função das várias colisões continentais que deram origem ao supercontinente Gondwana (Alkmim et al., 2017). 
As rochas que afloram em grande parte dos estados de Minas Gerais, Espírito Santo e Bahia são as raízes desta antiga cadeia de montanhas, expostas devido ao contínuo processo de erosão. A oeste do Orógeno Araçuaí, na região hoje ocupada pela bacia hidrográfica do São Francisco, encontra-se o Cráton do São Francisco, remanescente de um dos paleocontinentes envolvidos neste grande processo colisional.

No interior do Orógeno Araçuaí, ocorrem diversos blocos de embasamento, compostos por rochas mais antigas que 1,8 Ga, remobilizados durante o processo colisional (NOCE et al., 2007). É o caso, por exemplo, do Bloco Guanhães situado imediatamente a sul da área estudada, onde ocorrem rochas arqueanas e paleoproterozoicas de natureza metamagmática - como os ortognaisses do Complexo Guanhães - ou metassedimentar, como os quartzitos da Formação Serra Negra, que estruturam os abrigos aqui estudados.

Para a Arqueologia tais informações são importantes para a compreensão do uso da matéria-prima para a produção de conjuntos líticos. Em Três Fronteiras, diferente de áreas próximas, como é o caso do Planalto Diamantinense estudado por Andrei Isnardis (2009), o quartzito quase não faz parte do conjunto artefatual, raramente utilizado como percutor ou bigorna em forma de seixos. Mais de $90 \%$ dos vestígios componentes dos conjuntos evidenciados e estudados são de quartzo, sobretudo na forma anédrica, fator que influenciou os processos de gestão e produção das ferramentas líticas. Aqui o sílex, mesmo que com pouca 
expressão, aparece em maior número que nas áreas de entorno. Além disso, em Três Fronteiras, em especial, afloramentos de laterita ferruginosa (com goethita e hematita) ocorrem em todo entorno dos sítios arqueológicos, fonte de matériaprima para a produção de pigmentos.

Em termos geomorfológicos, a área em estudo pode ser caracterizada como morros do tipo meia laranja, característicos dos mares de morros mineiros (Knegt, 2015). Em Três Fronteiras o relevo é ondulado, marcado por quebras topográficas (patamares) escalonados, com a presença marcante de vales, depressões e alvéolos, colmatado por material aluvionar e eluvial.

Como já dito, o Complexo está dividido por duas micro-bacias: do córrego Água Quente, afluente do rio Santana (ao sul), e do córrego do Lambari Dourado, afluente do rio Itanguá (ao norte). Ambos fazem parte da bacia do rio Araçuaí que, por sua vez, é o principal afluente da margem direita do Jequitinhonha. Localmente, é uma área bem irrigada, com disponibilidade de água todo o ano, que se encontra muito próxima aos sítios arqueológicos.

De acordo com a classificação de Köppen-Geiger, o clima é tropical de altitude (Cwb), caracterizado por verões brandos e úmidos e invernos mais frescos e secos. Os índices de precipitação variam de $1250 \mathrm{~mm}$ a $1550 \mathrm{~mm}$ e temperatura média não ultrapassa os $20^{\circ} \mathrm{C}$, tendo uma variável entre $18^{\circ}$ a $19^{\circ} \mathrm{C}$ (Knegt, 2015). 


\section{CARACTERÍSTICAS DE IMPLANTAÇÃO DO ABRIGO 7}

O abrigo Três Fronteiras no 7 traz algumas peculiaridades em relação aos demais componentes do Complexo e, justamente por isso, foi o primeiro a ser eleito para intervenções. Primeiramente, é um dos poucos com processo de sedimentação em seu interior e, a princípio, com pacote sedimentar profundo, a exemplo do sítio Cabeças 04. Cabe destacar que toda a área de pesquisa é marcada pela presença de solos pouco profundos, geralmente arenosos, não sendo diferente nos abrigos que, muitas vezes, nem mesmo apresentam piso sedimentar ou a camada é extremamente curta, mal alcançando os $10 \mathrm{~cm}$ de profundidade, fator que, em certo modo, dificulta as análises estratigráficas, inclusive com 'esmagamento' das camadas médias de ocupação. Logo, abrigos com pacotes estratigráficos mais profundos trazem informações valiosas para a compreensão dos processos de ocupação regional na SdEM (Fagundes, 2016; Isnardis, 2013).

O abrigo foi formado a partir do abatimento de grandes blocos, ação que permitiu a proteção da luz direta e da chuva. Em seu interior, a entrada da luz natural é restrita, com luminosidade média ao longo do dia. O piso é plano e regular, com pequena declividade para norte/oeste, constituído por um amplo espaço sedimentar que, dada às características topográficas, está protegido de enxurradas. Em sua superfície, antes das intervenções, ao norte foram evidenciados um tronco de árvore de médio porte, folhas e algumas fezes de gado, mesmo assim os impactos na área eleita para escavação foram baixos. Durante o processo interventivo, foi observado que em subsuperfície havia poucas raízes, na verdade 
apenas radículas, sem qualquer vestígio de bioturbações, como cupins e formigas. Neste sentido, podemos apresentar os pacotes sedimentares do Três Fronteiras $\mathrm{n}^{\mathrm{0}} 7$ como bem preservados.

O sítio $\mathrm{n}^{\mathrm{0}} 7$ apresenta uma implantação muito discreta, sobretudo em relação aos outros afloramentos, a exemplo dos sítios 06 e 08 . As dimensões do sítio são 8,50 $\mathrm{m}$ de comprimento por 6,20 $\mathrm{m}$ de largura, um espaço de aproximadamente 52,7 $\mathrm{m}^{2}$, com altura média do teto $2,75 \mathrm{~m}$ (centro do abrigo), implantado em média vertente, distante aproximadamente $130 \mathrm{~m}$ da margem direita do córrego Lambari Dourado (afluente da margem esquerda do rio Itanguá), (Figura 3).

O abrigo apresenta aberturas para norte/ sul e leste/oeste, ou seja, é possível acessá-lo de todas as direções, sendo que as aberturas sul e oeste têm entrada mais fácil em relação às demais. O norte do abrigo está voltado para o sítio $\mathrm{n}^{\mathrm{o}} 6$ e seu painel rupestre principal, com presença de vários pequenos afloramentos no caminho. Ou seja, o acesso ao abrigo é muito simples, não havendo qualquer obstáculo, (Figuras 4 e 5). 


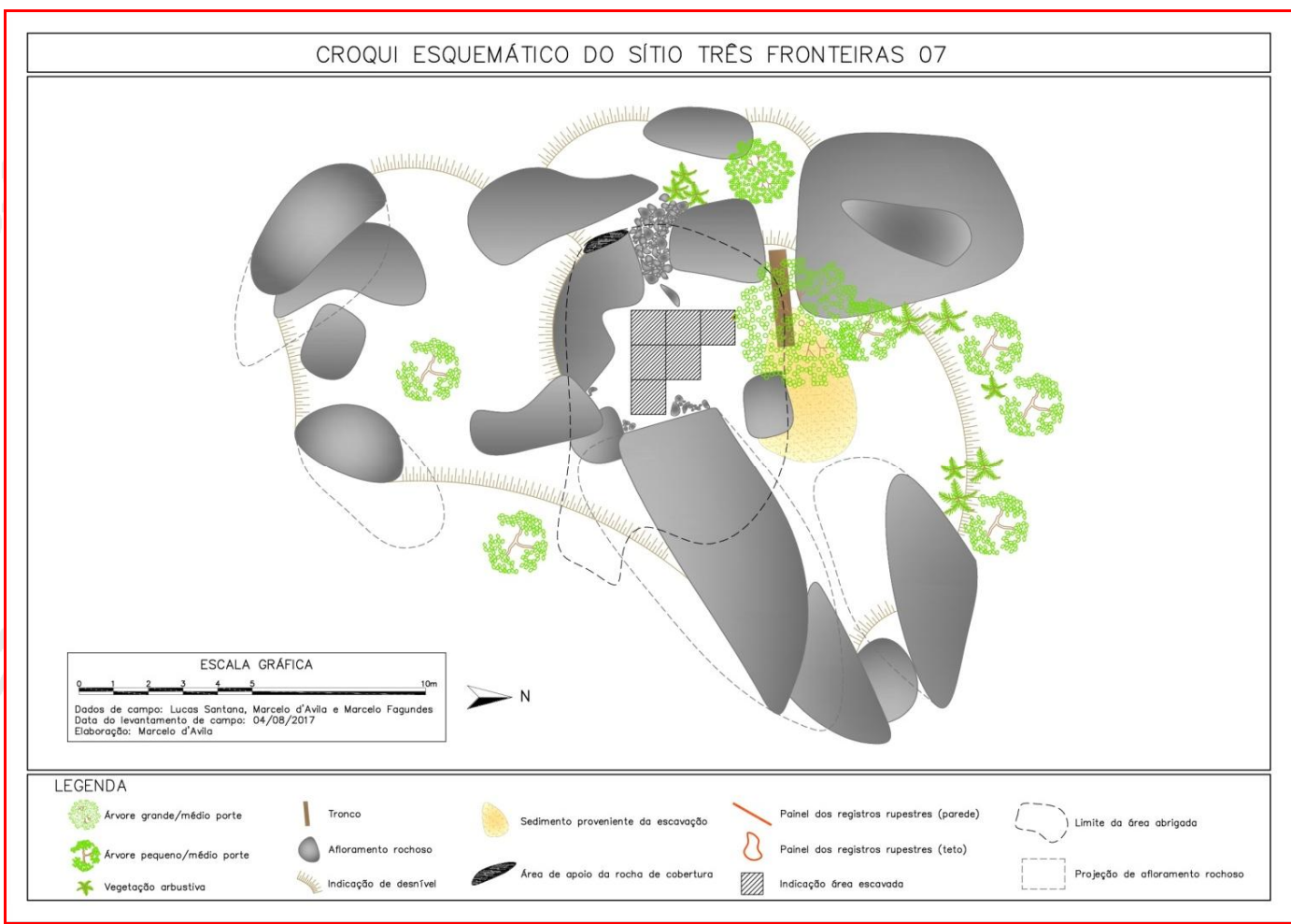

Figura 3. Croqui do sítio $\mathrm{n}^{\mathrm{0}} 7$, com destaque à área escavada.

Como apresentado, a luminosidade do sítio é média e durante o inverno apenas entre 9/10h da manhã foi possível observar incidência de luz solar direta em seu interior, por pouco tempo e apenas no setor norte. Apesar do fato de não termos realizado incursões ao sítio durante o período chuvoso (entre os meses de novembro e março), não havia marcas de ação direta da água no interior do abrigo e, desta forma, pode-se inferir que está bem protegido da chuva. 


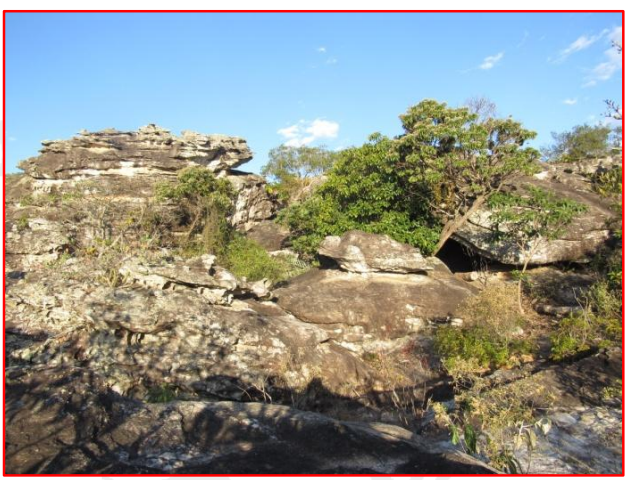

Figura 4. Entrada Oeste do Três Fronteiras $n^{0} 7$.

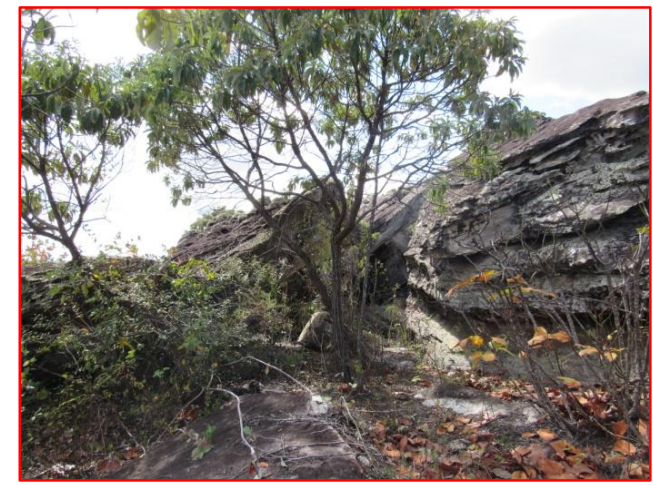

Figura 5. Entrada Sul do Três Fronteiras $\mathrm{n}^{\mathrm{o}} 7$.

Em suma, se entre os critérios elegidos pelos ocupantes do abrigo $\mathrm{n}^{\mathrm{o}} 7$ foi permanecer em lugares protegidos das intempéries naturais e discretos na paisagem, a análise dos atributos geográficos revela que este abrigo apresentou características ideias.

O entorno é constituído e modelado por vários afloramentos de quartzito que formam muitos abrigos, alguns com marcas evidentes de ocupação humana e outros não, sendo que os principais estão ilhados pelas nascentes do córrego Lambari Dourado. A imagem aérea deste lugar permite a visualização dos vários caminhos entre as rochas formados ao longo do tempo pelas diferentes ocupações humanas. Uma pequena plantação de eucalipto (ao leste) e o pasto a oeste são as intervenções recentes mais 'severas', sobretudo na face oeste, onde os sítios 09 a 
12 sofreram mais intervenções recentes, sobretudo o sítio 11, que foi utilizado com curral (Figura 6).

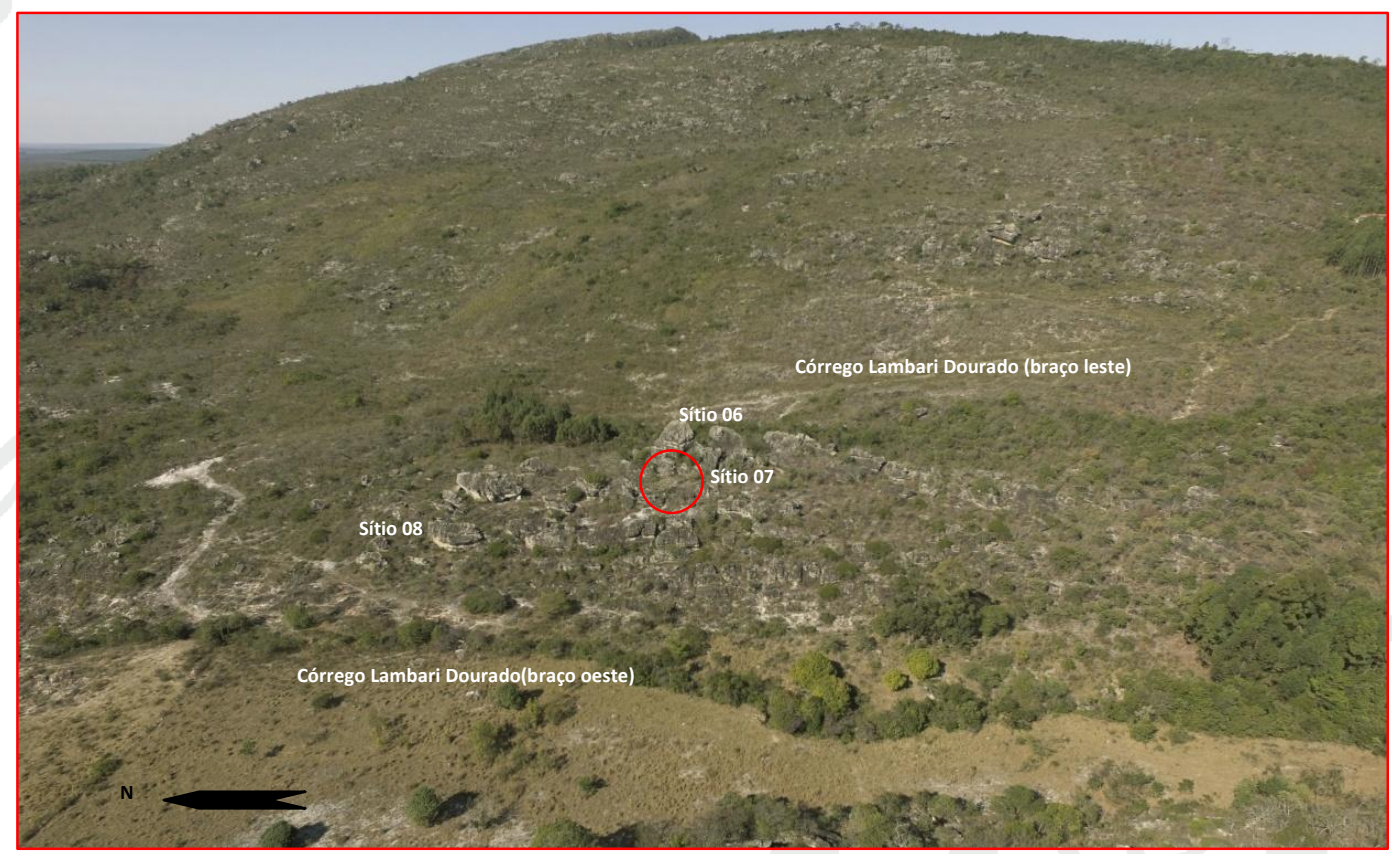

Figura 6. Complexo Arqueológico Três Fronteiras, vertente do Córrego Lambari Dourado. Destaque para o sítio 7. Observar os afloramentos em meio ao campo rupestre, a leste (parte baixa da imagem), mata ciliar do Água Quente.

Entre os abrigos com evidências de ocupação, contudo, algumas características de implantação são similares, dentre elas: 
- Todos apresentam entrada voltada para leste, alguns como é o caso do sítio 7, 08, 01 e 03 apresentam mais de uma entrada;

- Todos são abrigos de muito fácil acesso, sempre próximos de curso d'água, nunca ultrapassando $150 \mathrm{~m}$;

- Os pisos são sempre planos/ regulares nos abrigos. Exceção com relação a alguns compartimentos, geralmente mais altos que a superfície, como é o caso do sítio 08, sobretudo onde foram confeccionados grafismos. É importante destacar o fato de que em alguns abrigos, mesmo tendo um piso com pouca declividade, não apresentam pacote sedimentar e, portanto, não é possível escavações (sítios 01, 02, 06 e 05). Em outros a capa sedimentar é tão rasa que inviabiliza uma intervenção, sobretudo em uma atividade que requer controle estratigráfico;

- O entorno direto dos abrigos também apresentam topografia suave/ plana. No caso dos abrigos da vertente do Água Quente estão implantados em alta vertente, já os abrigos do Lambari Dourado em baixa vertente.

Todos apresentam grafismos rupestres, porém o único painel complexo e denso (inclusive com sobreposições) é o sítio 6. O sítio 8 apresenta densidade de figuras, mas todas isoladas, não há relações visíveis entre elas. O sítio 3, destruído por ação de vandalismo, apresentava um painel com relações de sobreposição e justaposição (Figura 8). Nos demais há baixa densidade de grafismos, sempre isolados. 


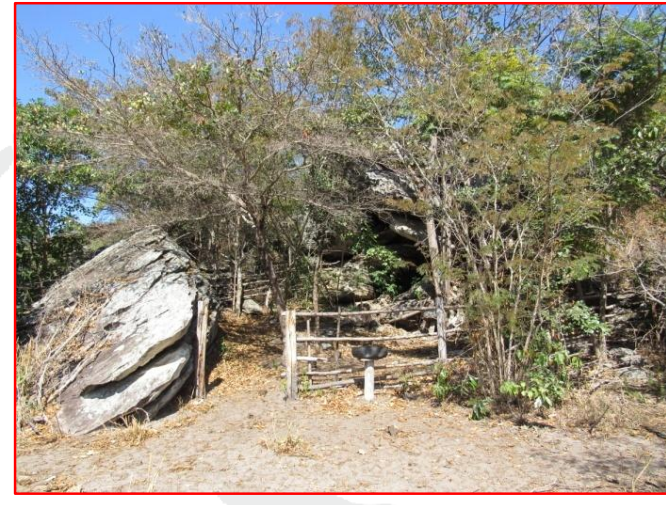

Figura 7. Sítio 11, atualmente um pequeno curral.

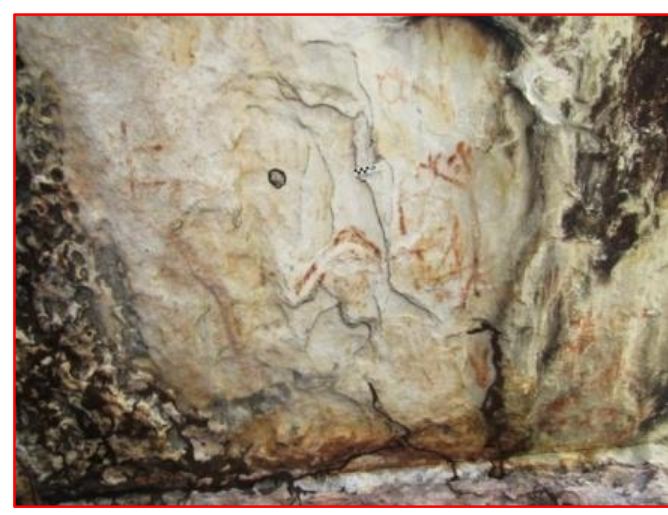

Figura 8. Painel rupestre do sítio 3, hoje destruído por ação criminosa.

\section{MATERIAIS E MÉTODOS: A ESCAVAÇÃO}

A escavação do Três Fronteiras no 7 ocorreu em uma campanha durante julho de 2017. A parte central do sítio foi quadriculada na direção norte-sul, sendo primeiramente delimitada uma trincheira de $3 \mathrm{~m}$, quadriculadas de metro em metro e denominadas de $\mathrm{J} 10 / \mathrm{J} 11 / \mathrm{J} 12$. O marco zero foi demarcado a partir da $\mathrm{J} 12$, distante $2,10 \mathrm{~m}$ para leste. A escavação foi realizada por decapagens naturais, respeitando a topografia natural do terreno e os processos formativos. A intenção ao executar esta trincheira foi explorar e avaliar o potencial do sítio, evidenciando o (s) pacote (s) de ocupação e, em seguida, dar continuidade ao processo caso avaliássemos pertinente. 
Em superfície o sedimento encontrava-se bem solto, pouco compactado, arenoso e com grandes grânulos de quartzo, de tonalidade cinza clara. Algumas pequenas lascas e estilhas foram evidenciadas no processo de limpeza. Com a continuidade do processo interventivo, o sedimento torna-se mais fino, ainda arenoso, porém de tonalidade cinza escuro, característica que perdura por todo este primeiro pacote (na transição do nível 02 para o 03), como discutiremos a seguir.

A maior densidade de material lítico ocorreu entre os níveis 04 e 05 (camada 02), onde foi possível evidenciar uma rica indústria em quartzo, mas também com a presença de vestígios em quartzito e sílex. Este comportamento foi observado na primeira trincheira, bem como nas demais quadrículas delimitadas. Esta camada, bem marcada estratigraficamente, é representada por um sedimento arenoso, bem fino, de compactação média e tonalidade entre branco e cinza bem claro.

Assim, ao término da trincheira, e posterior análise estratigráfica, delimitou-se a presença de três pacotes estratigráficos distintos. O material lítico ocorre em densidade (e diversidade), sendo majoritariamente composto por quartzo, mas com grande expressão de vestígios em sílex quando comparado com demais sítios regionais escavados (Figuras 11 e 12). Além da cultura material lítica, foram evidenciadas uma estrutura de combustão (Estrutura $01-$ J10, nível 7) e uma mancha escura difusa (Estrutura 02 - J12, nível 06), entretanto, a quantidade de carvão foi insuficiente para datações. Somados os fatos da diversidade/ densidade de cultura material lítica e impossibilidade de datações dos conjuntos, a equipe 
decidiu ampliar a escavação para o setor leste, abrindo uma nova trincheira de $2 \mathrm{~m}$ (I11/ I12) e apenas uma quadrícula mais próxima à parede do abrigo (H12).

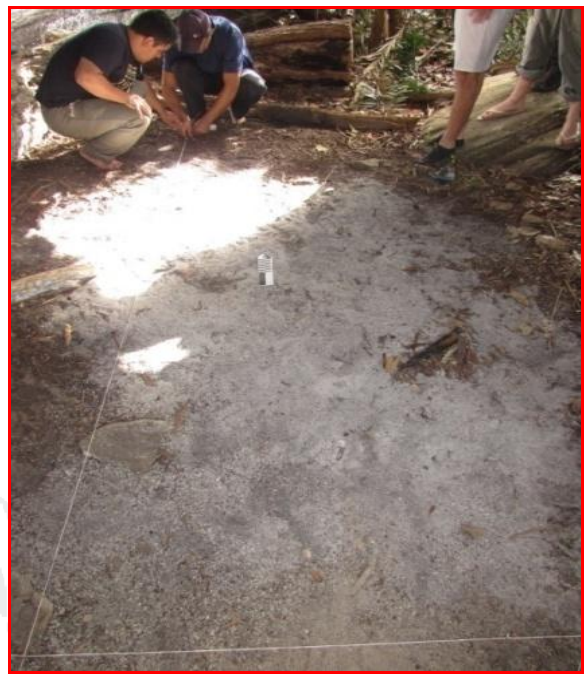

Figura 9. Quadriculamento, superfície.

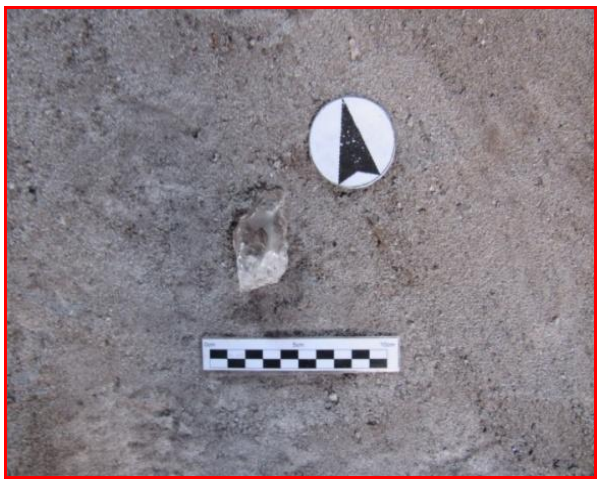

Figura 11. Artefato sobre lasca em quartzo hialino evidenciado no nível 04 , quadrícula J11.

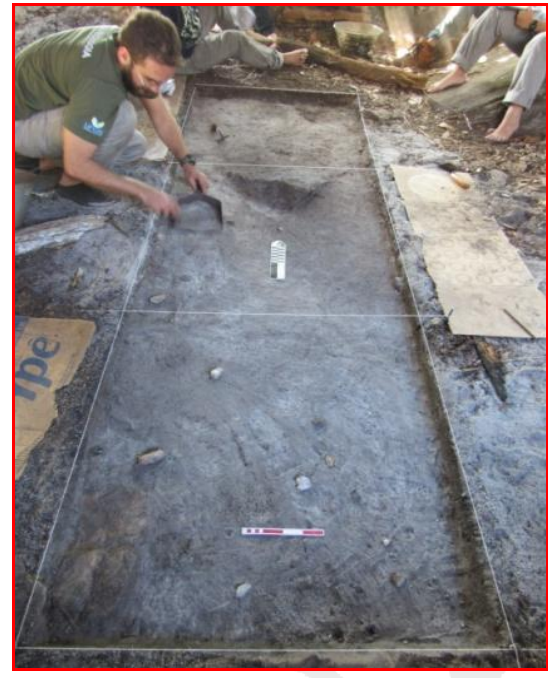

Figura 10. Nível 03 da escavação e material lítico evidenciado.

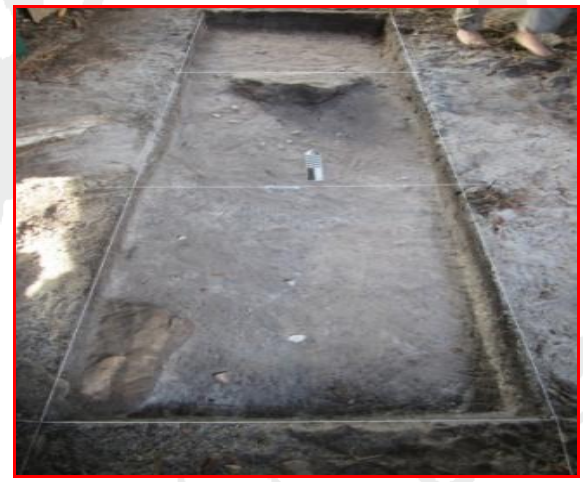

Figura 12. Concentração de vestígios líticos no nível 05. 
Com a expansão da escavação nas novas quadrículas, percebe-se uma continuidade do que havia sido observado na análise estratigráfica do perfil Oeste. Na Quadrícula I11, na transição do nível 03 para o nível 04, ocorre uma abundância de carvão e, desta vez, com quantidade suficiente para datação, sendo denominada de Estrutura 03, com extensão entre o final do nível 03 até o nível 05 (Pacote 02 de ocupação). No setor norte da quadrícula H12, entre os níveis 04 e 05, associada a uma grande soma de material lítico, foi evidenciada a Estrutura 04. Trata-se de uma fogueira estruturada, entre blocos, sendo parte dela estava no setor norte da H12, mas prosseguindo para a H11, com grande número de fragmentos de carvão. Entre os líticos exumados, no centro da fogueira foi retirado um percutor em quartzito.

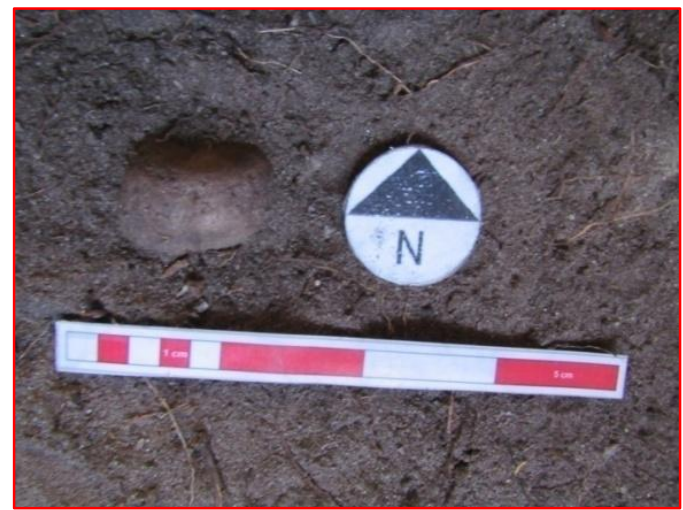

Figura 13 Estrutura 04.

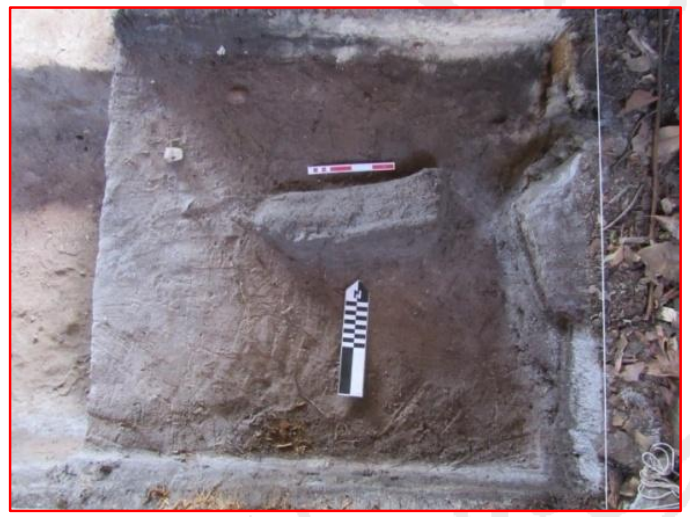

Figura 14 Percutor em quartzito associado à estrutura 4. 
O comportamento estratigráfico permaneceu o mesmo nas seis quadrículas escavadas, desta forma, havendo a evidenciação de três camadas (pacotes) distintas, resultando na evidenciação de quatro estruturas e um total de 4157 vestígios líticos. Sobre as camadas/ pacotes pode-se sintetizar (Figura 15):

Camada 01 (entre a superfície e os níveis 2/3). Na J10 esta camada é mais profunda, sobretudo em função do acúmulo de matéria orgânica no setor norte do sítio, inclusive foi a área com maior quantidade de raízes da escavação, permanecendo até a base, comportamento não recorrente nas quadrículas do setor sul (J12/ I 12/ H 12). O sedimento de tonalidade cinza escuro (variando entre tonalidades mais escuras até um cinza mais médio na verdade, sendo que no setor norte há pequenas lentes de areia mais claras), arenoso (na superfície com grânulos de quartzo maiores, mas diminuindo conforme a escavação foi sendo executada), com compactação muito baixa na superfície e aumentando em profundidade. Há poucos vestígios líticos associados, a maioria em quartzo, mas também há materiais em quartzito e sílex. Nenhum outro tipo de cultura material foi evidenciado (faunístico, botânica ou cerâmica, por exemplo). Não há estruturas de combustão, nem fragmentos de carvão espaçados;

Camada 02 (entre os níveis 3/4 seguindo até a transição do nível 06 para o 7) trata-se de um pacote marcado pela presença de sedimento arenoso, variando entre a tonalidade cinza claro e branca. Aqui foram evidenciadas quatro estruturas de combustão, sendo que a estrutura 04 foi datada em $4100 \pm 30$ anos AP (BETA 
471281). O conjunto lítico evidenciado apresenta grande diversidade, com matérias de diferentes morfologias, com predomínio de lascas brutas em quartzo. A presença do sílex é bem significativa, sobretudo quando comparado com outros sítios escavados e, diferente dos conjuntos do Planalto Diamantinense (ISNARDIS, 2009), o quartzito se faz pouco presente, geralmente associado aos instrumentos não-modificados (como percutores). Pode-se inferir, deste modo, um contexto ocupacional bem definido nesta camada, marcado por uma grande densidade e diversidade de material lítico, que permite a inferência de que o processo redutivo tenha ocorrido no interior do abrigo (o conjunto abriga lascas de diferentes morfologias, artefatos, núcleos, percutores e muitos refugos). Vestígios arqueobotânicos e faunísticos estão ausente no registro arqueológico, bem como a cerâmica, completamente ausente, uma característica regional (Fagundes, 2013; Isnardis, 2013);

Camada 03 (da transição entre o nível 06/07 até a base) - camada marcada pela presença de sedimento arenoso, de tonalidade marrom claro, mais compactado, seguindo estável até o embasamento rochoso. Diferente das demais camadas, há uma grande densidade de cascalhos associados, sobretudo decorrendo do processo de decomposição da rocha-base. Há baixa densidade de material lítico associado, provavelmente percolado dos níveis superiores, sendo que próximo a sua base, os níveis são estéreis. 


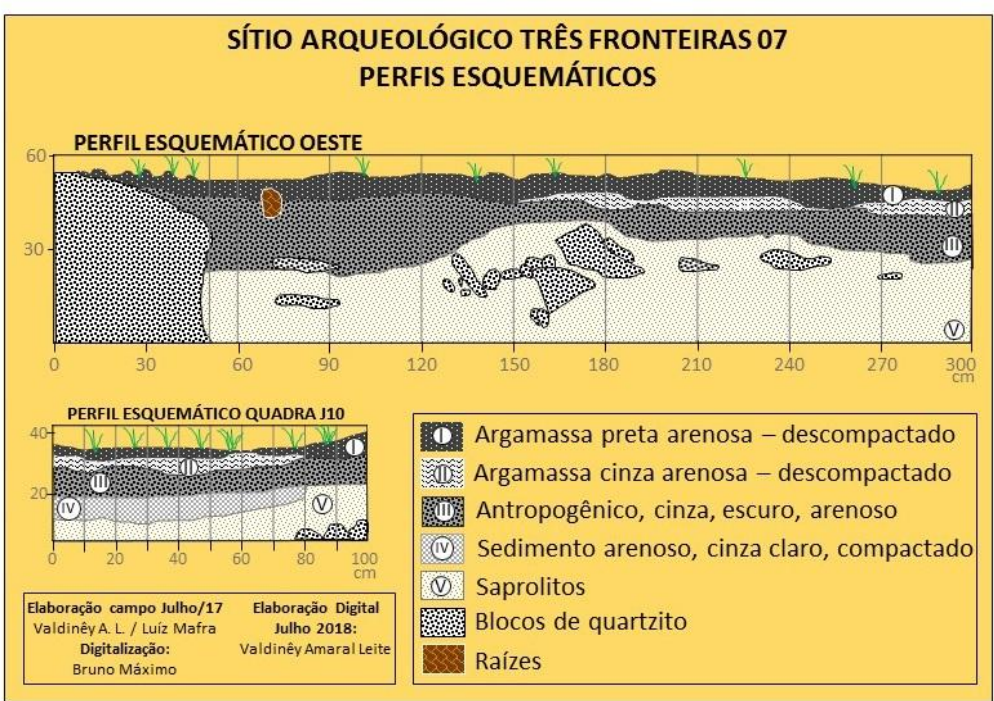

Figura $15 \quad$ Perfil esquemático da escavação do sítio Três Fronteiras 7.

\section{REPERTÓRIO CULTURAL}

A matéria-prima utilizada para confecção dos instrumentos encontra-se muito próxima aos sítios, em áreas de afloramentos de blocos de quartzo (anédricos), característica que estamos relacionando à escolha pelo lascamento unipolar, marcado pela baixa redução dos instrumentos e demonstrando pouco investimento. Esta realidade também foi observada em outras áreas, a exemplo de Campo das Flores (Perillo Filho, 2016) e região dos sítios Cabeças (Silva, 2017). Nesta perspectiva, o tipo de ocupação nos abrigos, seguido pela grande disponibilidade de matéria-prima estariam diretamente relacionadas às estratégias de produção, uso e descarte dos conjuntos líticos (Andrefsky, 2005). 
O conjunto artefatual lítico do Três Fronteiras nº 7 está constituído por 4157 peças de diferentes tipologias e matérias-primas. Acerca da matéria prima, o quartzo está representado por $95,88 \%$ do total, seguido pelo sílex 3,22\% do conjunto. O arenito silicificado, hematita e quartzito juntos equivalem a $0,9 \%$ dos materiais líticos evidenciados na escavação.

Neste sentido, o conjunto lítico do sítio Três Fronteiras $\mathrm{n}^{\mathrm{0}} 7$ é marcado pelo domínio do quartzo para a produção de instrumentos, com uso direito e, em alguns poucos exemplares, o uso do retoque. Por outro lado, entre os vestígios recuperados na escavação, há uma quantidade significativa de pequenas lascas de façonagem, um indicativo que artefatos poderiam estar sendo produzidos localmente e levados para outras áreas, no entanto, in situ os refugos do processo de lascamento abrangem $98 \%$ do conjunto artefatual em quartzo, sendo que suportes e artefatos têm número inexpressivo.

O material em sílex é minoritário, estando representado por pequenas estilhas e lascas de façonagem. O mesmo ocorre com os arenitos silicificados evidenciados, todos são pequenas lascas do processo de façonagem. Já as hematitas e quartzitos são refugos, sem qualquer marca de uso/ apropriação.

A arte rupestre regional está sendo estudado por Palhares (2018), em sua dissertação de mestrado. De modo geral, está assinalada pela forte presença da temática Planalto, onde predominam os cervídeos entre os grafismos. Outros 
quadrúpedes, peixes e antropomorfos filiformes também são recorrentes. Diferença em relação às demais áreas onde a Planalto se faz presente, por exemplo, além da baixa recorrência da associação de peixes e cervídeos (os peixes ocorrem no sítio 8, sempre isolados), as representações dos mamíferos quadrúpedes são estilizadas ou produzidas com menos complexidade de detalhes como ocorre em outras regiões próximas (Linke, 2008; Greco, 2017).

No que tange às técnicas, foi observado majoritariamente a pintura (em todos os sítios do Complexo) e o crayon com representações de cervídeos, produzidos exclusivamente no sítio 8. Todas são pinturas monocromáticas (em diferentes tonalidades de vermelho) e em número reduzido de tonalidades de amarelo.

Acerca da densidade dos grafismos, há diferentes realidades em Três Fronteiras: (a) Painel com grande quantidade de grafismos, em sobreposição e justaposição, caso exclusivo do principal painel do sítio 6; (b) sítios sem grandes painéis, as com mais de 20 grafismos produzidos, caso dos sítios 3,8 e 15; (c) sítios com reduzida quantidade de grafismos (menos que 5) e em alguns casos, sendo confeccionado apenas uma figura (sítio 1, 2, 4, 5, etc.). Os sítios com baixa densidade de pinturas são os mais 'discretos' na paisagem regional.

Partimos da hipótese que há um sítio core no Complexo (sítio 6), com a produção de um painel com grande densidade de figuras e, principalmente, produzidas para serem vistas (Figura 16). Os demais fazem parte desta grande assembleia que 
estamos denominando de Complexo, ou seja, temos a hipótese que os abrigos fazem parte de um único sítio, uma paisagem arqueológica.

Em suma, a arte rupestre do Três Fronteiras é marcada pela presença de grafismos com temática Planalto, porém com especificidades locais, sobretudo na escolha dos abrigos/ painéis que foram usados como suporte, bem como o tipo e densidade dos grafismos. Há painéis produzidos para serem vistos e outros, muito discretos, que partimos da inferência que sua produção estava vinculada a não identificação na paisagem, pelo menos para aqueles que não participaram diretamente da confecção da pintura/painel e, portanto, funcionariam como marcadores na paisagem, conectando os sítios/ lugares.

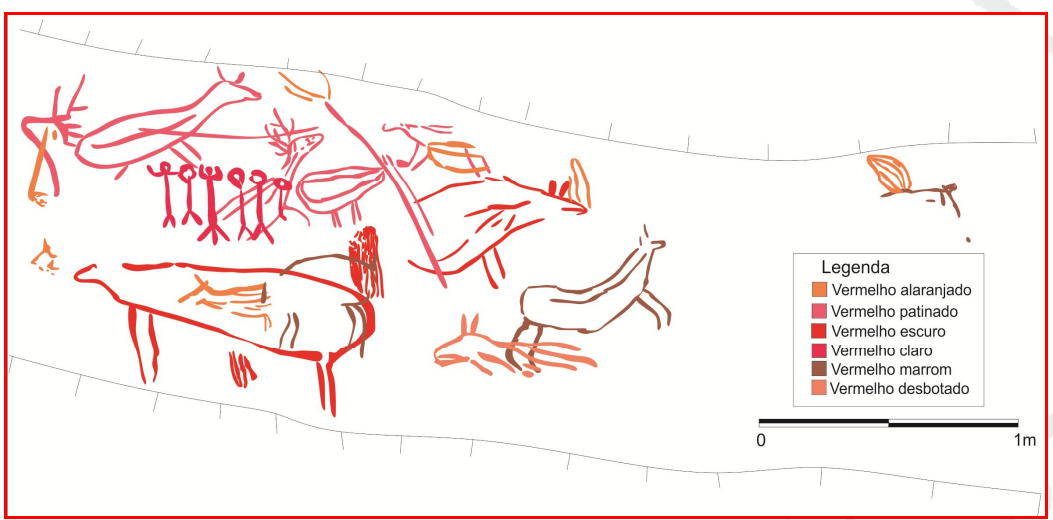

Figura 16 Painel principal do sítio 6. Foto e calque. Palhares/2018. 


\section{PALEOAMBIENTE, CRONOLOGIAS E OCUPAÇÕES HUMANAS DURANTE O HOLOCENO MÉDIO NA SERRA DO ESPINHAÇO MERIDIONAL, EM ESPECIAL EM SERRA NEGRA}

As discussões acerca do povoamento no Planalto Central Brasileiro durante o Holoceno não são novidades na literatura nacional. No que diz respeito ao Holoceno Médio hipóteses sugerem que haveria um período grande de estiagem que impulsionou o abandono de algumas áreas, sobretudo no que tange às ocupações dos abrigos (Araujo et al., 2005; Dias, 2005; Rodet et al., 2011; Bueno e Dias, 2015).

De acordo com Dias (2005), durante este período ocorreram muitas mudanças no clima sul americano (alguns eventos bem rápidos), registrando diferentes episódios de baixa taxa pluviométrica, possivelmente sendo esse um dos responsáveis pelo abandono de extensas áreas do Planalto Central. Ainda segundo a autora: "Estudios palinológicos en el Estado de Minas Gerais han demostrado rápidos cambios climáticos en este período, con fluctuaciones entre climas fríos y húmedos y calurosos y secos entre 9.000 y 5.000 años" (Dias, 2005, p. 253).

Araujo et al. (2005), com bases em estudos paleoambientais para o Carste de Lagoa Santa, em Minas Gerais (cerca de $200 \mathrm{~km}$ da nossa área de estudo), indicam que para a região o clima estaria muito mais seco durante todo o Holoceno Médio, coincidindo com o momento de decréscimo da população nos abrigos da região (salvo algumas exceções), bem como das lacunas cronológicas da área. Deste modo, levantam a hipótese de que: “(...) paleoclimatic changes 
were responsible for the patterns observed in the archaeological record of Central/Northern Brazil (Araujo et al., 2005, p. 300).

Para as inferências paleoambientais foram extraídas amostras de um lago de dolina próximo aos locais de pesquisa, a saber:

We generated some evidence suggesting the advent of dryer climatic conditions coincident with the "gap." A core sample extracted from the bottom of the temporary doline lake near the Cerca Grande outcrop revealed two discrete dark organic levels, the upper one at 50 $\mathrm{cm}$ depth, the lower at $210 \mathrm{~cm}$. We interpreted these levels as the result of two discrete periods of permanent water in the lake, hence two periods of higher humidity. The age obtained for the upper organic level was $2800 \mathrm{~T} 4014 \mathrm{C}$ yr B.P. (2900 T $100 \mathrm{cal} \mathrm{yr} \mathrm{B.P.),} \mathrm{and}$ for the lower level 9680 T $23014 \mathrm{C}$ yr B.P. (10,960 T $590 \mathrm{cal}$ yr B.P.). (Araujo et al., 2005, p.299).

Trata-se de uma questão complexa e, com pesquisas paleoambientais sendo desenvolvidas na SdEM, novas perspectivas sobre o paleoambiente regional têm sido apresentadas. Os dados até então produzidos para o Planalto Diamantinense e para Serra Negra (na borda leste da SdEM) indicam que ocorreram instabilidades climáticas durante o Holoceno variando entre clima frio-quente e úmido-seco. Contudo, para o Holoceno Médio, na maioria dos casos, observou-se um período mais estável, com clima quente e úmido, sobretudo entre 7000 e 4000 anos AP.(Hórak-Terra et al., 2011; Bispo et al., 2015).

Como base nesta informação mais sintética, alguns questionamentos arqueológicos têm sido formulados sobre as relações entre os humanos e seus 
ambientes, dentre as quais: (i) Qual a intensidade e tempo de desenvolvimento das mudanças climáticas? (ii) Quais os impactos na vida de populações? Cabe ressaltar que aqui partimos do pressuposto que as condições/ mudanças climáticas podem limitar escolhas, não determiná-las.

Neste sentido, a interpretação dos dados paleoambientais para a Arqueologia deve buscar a compreensão de como as mudanças ocorrem (curto, médio ou longo prazo), dos impactos causados no modo de vida e dinâmica ocupacional, sobretudo, levar em conta que as pessoas fazem escolhas, sobretudo porque se tratavam de grupos de caçadores-coletores em que a o modelo forrageiro e nômade seria o principal baluarte destas populações.

As pesquisas em turfeiras desenvolvidas pela UFVJM, coordenada pelo Dr. Alexandre Christófaro Silva, têm buscado a reconstituição paleoambiental regional utilizando uma abordagem multi-proxy: estratigrafia nuclear, análises palinológicas, isótopos $\mathrm{C}$ e $\mathrm{N}$, geoquímica e caracterização da cobertura vegetal (Silva et al., 2009).

Como exemplo, as pesquisas realizadas na turfeira de Pau-de-Fruta, município de Diamantina, indicaram diferentes episódios climáticos durante o Holoceno, com eventos de seca ou umidade, frio ou calor ao longo dos milênios. Assim, os resultados alcançados foram (Horák-Terra et al., 2015): 
- Clima frio e muito úmido entre 10.000 e 7.360 anos AP;

- Clima úmido e quente entre 7.360 e 4.200 anos AP;

- Clima seco e quente entre 4.200 e 2.200 anos AP;

- Clima seco com períodos de resfriamento entre 2.200 e 1.160 anos AP;

- Clima subúmido e ameno de 1.100 anos AP até o presente.

Com base na reconstrução paleoambiental desta turfeira, para o Holoceno Médio há um período úmido e quente (7.360 e 4.200 anos AP.), que coincidem com as datações dos sítios estudados, seguido por um período seco e quente entre $4200 \mathrm{e}$ 2200 anos A.P. É importante registrar que para esse momento mais seco, tanto no Planalto Diamantinense quanto para Serra Negra, as datações são mais restritas (Isnardis, 2009; Fagundes, 2016). No caso de Serra Negra por volta de 4000 anos há as cronologias que aqui serão discutidas e as datas dos sítios Cabeças 01, que variam entre 2500 e 2000 anos A.P.

Já as pesquisas realizadas em outra turfeira da SdEM (distrito de Pinheiro, município de Diamantina), obtiveram resultados para a reconstituição paleoambiental regional a partir de 60 mil anos AP. Para o período que nos interessa, os resultados foram (Hórak-Terra, 2014):

- Clima muito úmido e muito frio entre 16.400 e 6.600 anos AP;

- Clima seco e quente entre 6.600 e 3.300 anos AP;

- Clima quente e seco para subúmido de 3.300 anos BP até o presente. 
$\mathrm{Na}$ Área Arqueológica de Serra Negra, face leste da Serra do Espinhaço Meridional, a descoberta de novos sítios em abrigos quartzíticos e a intensificação das escavações, ambos têm revelado um novo quadro de ocupação regional (Figura 16). O Planalto Diamantinense, estudado por Isnardis (2013), é a região mais próxima de Serra Negra, distante cerca de $50 \mathrm{~km}$ em linha reta. Nele as cronologias seguem o modelo inferido pelo hiato do arcaico, com datas da transição do Pleistoceno para o Holoceno e aquelas relacionadas ao Holoceno Superior, havendo ausência de datações entre 7 e 2 mil anos AP.

Em Serra Negra, por outro lado, as datas mais antigas são do início do Holoceno Médio, por volta de 7200 anos AP., não havendo cronologias relacionadas ao período anterior (Holoceno Inferior). Até o momento, as escavações de três abrigos forneceram datas que sustentam a hipótese de ocupações constantes em todo o Holoceno Médio para a área. Entre as hipóteses levantadas para tal realidade, podemos enumerar:

Povoamento tardio desta borda leste do Espinhaço, com ocupações a partir de próximo de 8000 anos. Assim, as camadas estratigráficas inferiores (mais profundas) estariam associadas às ocupações durante o Holoceno Médio, evitando o 'esmagamento' destes pacotes. Nestes abrigos, as camadas médias estariam relacionadas às ocupações entre os limites de 4 e 2 mil anos AP., ou seja, há cronologias até próximo 4 mil anos AP. e um retorno de datas a partir de 2 mil anos AP. Logo, para Serra Negra, o hiato estaria entre estes milênios que, por 
inferência, são as camadas/ pacotes médios da ocupação nos abrigos. A análise dos perfis dos sítios Cabeças 4 e Três Fronteiras 7, ambos com superfície maior de intervenção, esta hipótese é bem fundamentada;

O processo de sedimentação diferente dos abrigos do Planalto Diamantinense, geralmente curtos, com pacotes que mal ultrapassam $20 \mathrm{~cm}$ e, neste caso, com este esmagamento das camadas médias (associadas ao Holoceno Médio, entre 7 e 2 mil anos AP).

Portanto, com base nestas hipóteses, a ausência de cronologias estaria muito mais vinculada às questões metodológicas do que climáticas, sobretudo no que tange à ocupação de abrigos. Em todo caso, ainda se trata de uma conjectura muito frágil, necessitando da ampliação das escavações e detalhamento mais preciso dos processos estratigráficos em Serra Negra;

Para as turfeiras das cabeceiras do rio Araçuaí, local onde estão implantados a maior parte dos sítios de Serra Negra (distante cerca de 4 km dos sítios Cabeças e cerca de $12 \mathrm{~km}$ de Três Fronteiras), as pesquisas resultaram em dados que, em síntese, demonstram uma mudança para clima mais úmido entre 7664 e 4226 anos AP., com predominância das gramíneas em torno de 7664 anos AP. e uma mistura maior de espécie ao final deste período, sobretudo com presença de lenhosas (Bispo et al., 2015). 
Para a turfeira do Rio Preto, município de São Gonçalo do Rio Preto - MG (muito próxima ao sítio Cabeças 4), os resultados alcançados para o Holoceno Médio indicaram que temperaturas estavam mais baixas e clima úmido a partir de 7.000 anos AP. até o presente (Costa, 2018).

Ainda para a área onde está implantado o sítio Cabeças 4 (e entorno), as análises de Chueng et al. (2018) sobre reconstituição paleoambiental, tem sido de suma importância para a compreensão dos modelos de implantação e apropriação da paisagem pelo grupo (s) que ocupou a área. Segundo os autores, os resultados das análises dos fitólitos realizadas tanto no interior da escavação do sítio, quanto em uma área fechada no entorno direto, indicaram a predominância de campos rupestres entre 7225 e 4000 anos AP (cronologias do sítio arqueológico), com estresse hídrico moderado durante este período, ou seja, não se tratava de uma área de clima seco. Em síntese, os dados obtidos até então (a pesquisa está em andamento), a presença de gramíneas de altitude do sítio indica clima úmido para a área durante todo o Holoceno Médio (Chueng et al., 2018).

Estas investigações têm apontado que, pelo menos para parte do SdEM, ocorreram diferentes episódios climáticos durante o Holoceno, variando de frio para quente, seco para úmido. Contudo, para o Holoceno Médio, em especial, não ocorreram episódios de secas intensas ou drásticas, responsáveis pelo abandono da área.

O Cabeças 4 é um dos abrigos ocupados durante o Holoceno Médio, estando distante $4 \mathrm{~km}$ em linha reta das turfeiras que forneceram os dados de Bispo et al. 
(2015). Localizado na margem oeste do Araçuaí, no sopé da Serra do Gavião (Figura 17), foi o primeiro dos abrigos a fornecer datas do período, com sequência estratigráfica entre 7225 e 4420 anos AP, associados à camada 03 da escavação.

O material lítico exumado das camadas pertencentes ao Holoceno Médio do sítio Cabeças $n^{\circ} 4$ foi estudado por Silva (2017), que analisou um total de 1607 vestígios, sendo que $97,56 \%$ em quartzo, $1,74 \%$ materiais em quartzito; $0,06 \%$ em gnaisse e $0,62 \%$ em óxidos de ferro. Apesar da diversidade tipológica do conjunto, a grande maioria corresponde aos refugos dos processos de lascamento, totalizando $86,30 \%$ do conjunto. O restante está constituído por artefatos $(0,24 \%)$, lascas $(12,44 \%)$, percutor $(0,24 \%)$ e naturais $(0,43 \%)$. As técnicas identificadas no processo de produção das lascas foram: a percussão unipolar (direta/ dura), dominante no conjunto analisado resultando em 188 peças, ou seja, 94\% das lascas, além de uma presença discreta da percussão sobre bigorna, com 12 peças resultando em 6,0\% das lascas (Silva, 2017).

\begin{tabular}{|l|l|l|l|l|}
\hline LABORATÓRIO & \multicolumn{1}{|c|}{ MATERIAL } & MÉTODO & \multicolumn{1}{c|}{ DATA } & CALIBRAÇÃO \\
\hline BETA 379290 & Carvão estrutura de combustão & C14 & $6290 \pm 30$ & 7255 a 7170 \\
\hline BETA 379290 & Carvão estrutura de combustão & C14 & $6170 \pm 40$ & 7160 a 7100 \\
\hline BETA 370289 & Carvão estrutura de combustão & C14 & $5270 \pm 40$ & 6180 a 6150 \\
\hline BETA 370291 & Carvão estrutura de combustão & C14 & $4010 \pm 10$ & 4520 a 4420 \\
\hline BETA 379289 & Carvão estrutura de combustão & C14 & $3890 \pm 30$ & 4445 a 4420 \\
\hline
\end{tabular}

Quadro 1. Datações associadas ao Holoceno Médio do sítio Cabeças 04, Felício dos Santos, Nordeste de Minas Gerais. 
O segundo abrigo que obteve datações associadas ao Holoceno Médio foi o Sampaio. Com a escavação do nível 09, camada de ocupação 03, no perfil SW, foi evidenciada uma estrutura de combustão (estrutura 03), com presença de grandes fragmentos de carvão, com material lítico em quartzo associado. O material foi datado por Carbono 14 no laboratório Beta Analytic (Miami, EUA), resultando em uma cronologia de $4280 \pm 30$ anos AP (BETA 471280), calibrada entre 4866 4799 anos AP.

O conjunto lítico associado foi estudado por Galvão (2017) que, segundo suas análises, é um conjunto predominantemente em quartzo que corresponde a $84,96 \%$ do conjunto, seguido pelo quartzito $(14,11 \%)$, óxidos de ferro $(0,61 \%)$ e o sílex $(0,61 \%)$, sendo que uma das características principais é o lascamento unipolar como única utilizada neste conjunto. No que se refere à tipologia, o conjunto artefatual observou-se a presença majoritária dos refugos de lascamento (91,70\%), seguido por artefatos e instrumentos (2,44\%), lascas $(4,29 \%)$ e plaquetas naturais $(1,53 \%)$. 


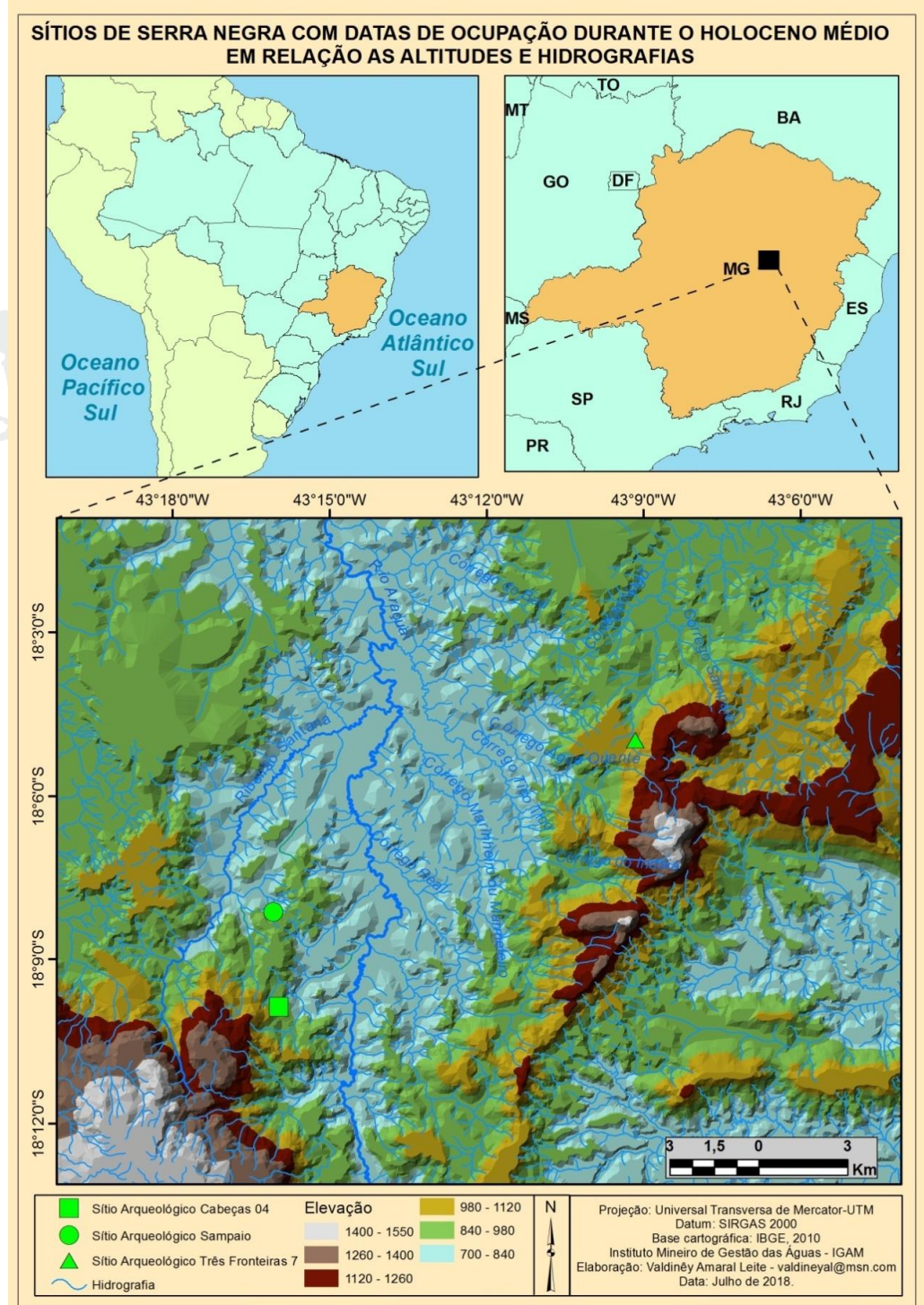

Figura 17. Sítios de Serra Negra com datas de ocupação durante o Holoceno Médio em relação às altitudes e hidrografia. Fonte: IBGE/2000. 
No caso do Três Fronteiras $\mathrm{n}^{\mathrm{o}} 7$ apenas a estrutura 03 forneceu material suficiente para datação, que, enviada ao Beta Analytic, obteve cronologia associada ao Holoceno Médio de $4100 \pm 30$ anos AP (BETA471281), calibrada em 4643 4424 anos AP.

Em suma, observa-se que para essa região em Serra Negra, no Alto Araçuaí, as ocupações humanas se mantiveram ao longo de todo o Holoceno Médio, entre 7225 e 4424 anos AP. Sob nosso ponto de vista, particularidades sócio-ambientais foram responsáveis para uma ocupação contínua regional, com clima estável (quente e úmido durante este período), conforme as análises realizadas nas turfeiras e com fitólitos obtidos na região do Cabeças. As análises paleoambientais estão em processamento e, certamente, com a continuidade das pesquisas, novos dados (ambientais e culturais) poderão fornecer interpretações mais assertivas acerca da ocupação pré-colonial regional.

\section{CONCLUSÕES}

O sítio Três Fronteiras $n^{0} 7$ é, certamente, um dos abrigos mais importantes regionalmente que, associado ao Cabeças 04 e Sampaio, trouxeram a luz novos dados acerca de ocupações humanas durante o Holoceno Médio para a região de Serra Negra, borda leste da Serra do Espinhaço Meridional, área que, conforme os estudos paleoambientais apresentados, apresentou um clima estável (quente e úmido) durante grande parte do Holoceno Médio e, portanto, uma hipótese de esvaziamento populacional em função mudanças climática não se sustenta, além 
do fato que, conforme pressupostos aqui adotados, o abandono ou permanência de uma área diz respeito às escolhas, sobretudo levando em conta o tempo e extensão dos câmbios ambientais no Brasil durante o Holoceno como um todo.

No que tange aos conjuntos líticos percebe-se que estão de acordo com aqueles já estudados para os abrigos com ocupações do Holoceno Médio: uso majoritário do quartzo, obtido facilmente no entorno do sítio sob a forma anédrica e, tal fato, pode ser a justificativa mais plausível para o uso predominante da técnica unipolar.

A arte rupestre, por sua vez, apesar de apresentar em seu conjunto a temática associada à tradição Planalto, observa-se a presença de grafismos mais estilizados, sobretudo os cervídeos, com quase inexistência da associação cervídeo e peixes, e com densidade de grafismos nos painéis bem mais baixa do que se observa em outras regiões, com exceção do sítio 6 que, conforme apresentado, estamos considerando como o abrigo core, onde o painel foi confeccionado para ser visto. A continuidade da pesquisa (o sítio Matão será escavado em setembro de 2018) e a obtenção de novos dados (tecnologia lítica, pesquisas paleoambientais e novas cronologias), cooperarão para a compreensão assertiva acerca da implantação dos sítios na paisagem, da própria formação do registro arqueológico e tecnologias associadas. 


\section{REFERÊNCIAS BIBLIOGRÁFICAS}

ALKMIM, F. F., KUCHENBECKER, M., REIS, H.L.S., PEDROSA-SOARES, A.C. The Araçuaí Belt. In: Heilbron, M., Cordani, U.G., Alkmim, F.F. 2017. São Francisco craton: Tectonic Genealogy of a Miniature Continent. Regional Geology Reviews, Springer, p. 255-276, 2017.

ANDREFSKY, William. Lithics: macroscopic approaches to analysis. New York: Cambridge University Press, 2005.

ARAUJO, Astolfo et al. Holocene dryness and human occupation in Brazil during the “Archaic Gap"”. Quaternary Research, 64, 298-307, 2005.

BINFORD, Lewis R. The archaeology of place. Journal of Anthropological Archaeology, 1, pp.5-31, 1982.

BISPO, D. et al. Characterization of Headwaters Peats of the Rio Araçuaí, Minas Gerais State, Brazil. Revista Brasileira de Ciência do Solo, 39 (2), p. 475-489, 2015.

BUENO, Lucas; DIAS, Adriana S. Povoamento inicial da América do Sul: contribuições do contexto brasileiro. Estudos Avançados, 29 (83), pp. 119-147, 2015.

CHUENG, Karina et al. Reconstituição Paleoambiental da Área Arqueológica de Serra Negra, Face Leste do Espinhaço Meridional (Minas Gerais), através da Análise de Fitólitos. Revista Brasileira de Geografia Física (no prelo), 2018.

COSGROVE, Dennis. Social formation and symbolic landscape. London: Croom Helm, 1984.

COSGROVE, D. A geografia está em toda parte: cultura e simbolismo nas paisagens humanas. In: CORRÊA, R .L. ; ROSENDAHL, Z. (orgs.) Paisagem, Tempo e Cultura. Rio de Janeiro: EDUERJ, 1998.

COSTA, C. R. Estudo de reconstituição paleoambiental utilizando uma abordagem multi-proxy em um registro da turfeira do Rio Preto, Minas Gerais, Brasil. 130f. Dissertação (Mestrado) - Programa de Pós-Graduação em Produção Vegetal, Universidade Federal dos Vales do Jequitinhonha e Mucuri, Diamantina - MG, 2018. 
DIAS, Adriana S. Diversificar para poblar: El contexto arqueológico brasileño em La transición Pleistoceno-Holoceno. Complutum, vol. 15, pp. 249-263, 2004.

FAGUNDES, M. O Projeto Arqueológico Alto Jequitinhonha? Sítios Arqueológicos, Cultura Material e Cronologias para Compreensão das Ocupações Indígenas Holocênicas no Alto Vale do Rio Araçuaí, Minas Gerais - Brasil. Vozes dos Vales, v. 10, p. 01-25, 2016.

FAGUNDES, Marcelo. O Projeto Arqueológico Alto Jequitinhonha (PAAJ) e a Área Arqueológica De Serra Negra, Alto Araçuaí, Minas Gerais - Aspectos Gerais. Revista Espinhaço, v. 2, n.2, p. 68-95, 2013.

GALVÃO, Landerson. Estudo do conjunto lítico do sitio Sampaio, Felício dos Santos, MG. 112f. Monografia (Bacharelado em Ciências Humanas), Universidade Federal dos Vales do Jequitinhonha e Mucuri, Diamantina - MG, 2017.

GRECO, Wellington. Estilo e Paisagem: os conjuntos rupestres do sitio Sampaio, Felício dos Santos, Vale do Rio Araçuai, Alto Jequitinhonha, MG. 144f. Monografia (Bacharelado em Ciências Humanas), Universidade Federal dos Vales do Jequitinhonha e Mucuri, Diamantina - MG, 2017.

HORÁK, Ingrid et al. Pedological and isotopic relations of a highland tropical peatland, Mountain Range of the Espinhaço Meridional (Brazil). Revista Brasileira Ciência do Solo, v. 35, n. 1, p. 41-52, 2011.

HORÁK-TERRA, I. Late Pleistocene-Holocene environmental change in Serra do Espinhaço Meridional (Minas Gerais state, Brazil) reconstructed using a multi-proxy characterization of peat cores from mountain tropical mires. 134f. Tese (Doutorado) Programa de Pós-Graduação em Solos e Nutrição de Plantas, Universidade de São Paulo, 2014.

HÓRAK-TERRA, I.; MARTÍNEZ CORTIZAS, A.; DA LUZ, C.; FERNANDES PINTO; RIVAS LÓPEZ, P. ; SILVA, A. C.; VIDAL-TORRADO, P. Holocene climate change in central-eastern Brazil reconstructed using pollen and geochemical records of Pau de Fruta mire (Serra do Espinhaço Meridional, Minas Gerais). Palaeogeography, Palaeoclimatology, Palaeoecology, v. 437, p. 117-131, 2015. 
ISNARDIS, Andrei. Entre as pedras: as ocupações pré-históricas recentes e os grafismos rupestres da região de Diamantina, Minas Gerais. 280f. Tese (Doutorado) Programa de Pós-Graduação em Arqueologia, Museu de Arqueologia e Etnologia, Universidade de São Paulo, São Paulo, 2009.

ISNARDIS, Andrei. Pedras na Areia. As Indústrias Líticas e o Contexto Horticultor do Holoceno Superior na Região de Diamantina, Minas Gerais. Revista Espinhaço, 2 (2), p. 54-67, 2013.

KNEGT, L. M. P. Indicadores da paisagem para a ocorrência de sítios arqueológicos na Área Arqueológica de Serra Negra, face leste do Espinhaço. 164f. Dissertação (Mestrado) - Programa de Pós-Graduação em Geografia e Análise Ambiental, Instituto de Geociências, Universidade Federal de Minas Gerais, Belo Horizonte, 2015.

LINKE, V. Paisagens dos sitios arqueológicos de pintura rupestre da região de Diamantina - MG. 186f. Dissertação (Mestrado) - Programa de Pós-Graduação em Geografia do Instituto de Geociências, Universidade Federal de Minas Gerais, Belo Horizonte, 2008.

MACEDO, Thaisa D. Almeida. "Vou Te Proteger": a Educação Patrimonial como estratégia para proteção e valorização do patrimônio arqueológico do município de Felício dos Santos, MG. Programa de Pós-Graduação em Ciências Humanas, UFVJM, Dissertação de Mestrado, 2017.

NOCE C. M., PEDROSA-SOARES A.C., SILVA L. C., ARMSTRONG R.; PIUZANA, $\mathrm{D}$. Evolution of polyciclic basement complexes in the Araçuaí orogen, basedon $\mathrm{U}-\mathrm{Pb}$ SHRIMP data: Implications for Brazil-Africa links in Paleoproterozoic time. Precambrian Research, 159, p. 60-78, 2007.

PALHARES, Danilo. Pintando a Paisagem: uma Análise Do Complexo Arqueológico Três Fronteiras, Senador Modestino Gonçalves, Minas Gerais. 57f. Qualificação (Mestrado em Ciências Humanas), Programa de Pós-Graduação em Ciências Humanas, Universidade Federal dos Vales do Jequitinhonha e Mucuri, Diamantina - MG, 2018.

PERILLO FILHO, Átila. Análise lítica e dispersão dos materiais arqueológicos do sítio Itanguá 02, Vale do Jequitinhonha, MG. 128f. Dissertação (Mestrado em Antropologia), 
Programa de Pós-Graduação em Antropologia - Universidade Federal de Pelotas, Pelotas $-\mathrm{RS}, 2016$.

RODET, J.; DUARTE-TALIM, D; BARRI, L. F. Reflexões Sobre as Primeiras Populações do Brasil Central: “Tradição Itaparica. Habitus, 81-100, 2011.

SILVA, A.C.; HORÁK, I; VIDAL-TORRADO, P; MARTINEZ-CORTIZAS, A;

RODRIGUES RACEDO, J; CAMPOS, J. R. R. Turfeiras da Serra do Espinhaço Meridional - MG. II - Influência da drenagem na composição elementar e substâncias húmicas. Revista Brasileira de Ciência do Solo, 33, pp. 1399-1408, 2009.

SILVA, L. O Holoceno Médio na Serra Negra: Alto Vale do Araçuaí, Minas Gerais. 174f. Dissertação (Mestrado em Antropologia), Programa de Pós-Graduação em Antropologia - Universidade Federal de Pelotas, Pelotas - RS, 2017.

TRONCOSO, A. M. Espacio y Poder. Boletín de la Sociedad Chilena de Arqueología, n. 32, p.10-23, 2001.

ZVELEBIL, Marek. Hunter-gatherer ritual landscapes: spatial organization, social structure and ideology among hunter gatherers of northern Europe and western Siberia. Analecta Praehistorica Leidensia, 29, pp. 33-50, 1997. 